\title{
Hybrid UPQC arrangement for power quality improvement
}

\author{
Vodapalli Prakash ${ }^{1,}$, C Venkatesh ${ }^{2}$, and C.Pavan Kumar $^{3}$ \\ ${ }^{1}$ Kakatiya Institute of Technology \& Science, Warangal, T.S, India \\ ${ }^{2}$ Kakatiya Institute of Technology \& Science, Warangal, T.S, India \\ ${ }^{3}$ Kakatiya Institute of Technology \& Science, Warangal, T.S, India
}

\begin{abstract}
In the forthcoming gap, throughout the world storage systems will carry the leading role, the reason is of providing energy in distant places. The utilization of storage elements in almost all applications are tremendously changed by the researchers. Here, mentioning the theory to increase the quality benefits in all corners of power utilization. By summing potential elements such as Unified power Quality conditioner, fuel cell to suppress the problems at the consumer points. UPQC is capable to supporting dynamic conditions at combined common connection in the system. To achieve the consumer expectations in our country, Power Quality is a big subject as there are frequent power variations, outages and frequency. Hence, it is required to take crucial steps in the direction of the growth. This hybridization of different elements gives the research in the angle of improving several issues, for unbalanced distribution system. This paper comes up with a configuration of UPQC that incorporates DC -to-DC converter along with the fuel - cell at the DC-link side, the whole setup run under MATLAB environment.
\end{abstract}

\section{Introduction}

The nonlinear devices are increase in number every day, the power quality problems are multiplied by ' $n$ ' No.of times, slowly spoiling of the system and at the same time it is very tough for electrical engineers for eliminating the power issues [1]. With the continuos usage of power electronic converters, harmonics are injecting into the system. The latest equipments that are used in home and industries for various commercial applications are prone to harmonics and also effected with the poor power factor. In our daily life, some of the devices are delicate and produce harmonics also create voltage disturbances cause low power factor. This type of disturbances definitely create unwanted results. As a result, there may be a chance of network failure or break down of devices which spoil the delicate loads.

UPQC is also an acceptable approach for handling linear and non-linear burden on the system. Series active power filter of the same acts as DVR to sort out the voltage problems and shunt active power filter acts as STATCOM takes care of current distortions, a DC link shared by both filters [2-4], [20]. The fuel cell along with super capacitor can be used on the DC link for smaller durations. Fuel cells are employed in electric vehicles, UPS, hospitals, defence equipments and residential purpose [5-6] \& [9], because very low pollution, less mass, less volume. The rate of discharge is slower in batteries because of mild chemical reactions. Super capacitors can be observed in hybrid vehicles, buses, trains, elevators. The recent trend is changed to super capacitors, because of faster charge and discharge rate. The supercapacitors store less energy, whereas batteries normally having frequent maintenance with low discharge rate. Because of the merits such as higher power density, good efficiency and maintenance free etc., super capacitor are used [7-8].

Paper [10] describes the behaviour of a non-linear nature of a rectifier with $\mathrm{R}-\mathrm{C}$ load. In paper [11-12] information is about employment of Bi-directional full bridge DC-DC converters in UPQC. As per IEEE 5191992 standard accessible limit of source current THD is $5 \%$ in all successful working conditions. This hybrid system is set to reveal the importance of the UPQC, DC/DC converter and fuel cell system along with super capacitor. To nullify the harmonics in currents, voltages and strengthening of power factor value at the point of installation and also reduction of THD value. The operation of the presented system was simulated in the course of MATLAB environment. This work is presented as: Section 2; explains the hybridization of fuel cell with super capacitor based UPQC with DC-DC converter. Section 3; explains the series and shunt converter control method. Section 4; explains about analysis of results. Section 5; depicts the conclusion. Section 6; give out the appendix.

\section{HYBRID UPQC}

The hybrid UPQC shown in Fig.1. The active filters are using a dc link connected to a fuel cell along with super capacitor setting up by a sharing a dc capacitor.

\footnotetext{
* Corresponding author: vp.eee@kitsw.ac.in
} 
The VSI form shunt - filter is perfectly manage unwanted signals at input side as well changes on the behaviour in the burden of the system. The transformers will inject the voltages. Fig.2 presents the electrical equivalent models of super capacitor and fuel cell. For heavy applications, fuel cells will have some difficulties. For heavy sytems manufacturing cost is high, where the catalyst is used is expensive as well low power density and slow dynamic response [13]. This configuration combines a fuel cell as the basic energy source and another auxiliary element provide fast and extra power source operated for running the base load during peak time.

The generation of electricity from the chemical action. The reformer generates hydrogen gas from fuels and then provided to the stack. The stack has number of unit cells that are fabricated in combinations of series or parallel to produce more voltage depends on the applications [13] \& [15].



Fig. 1. Showing Hybrid UPQC [17].

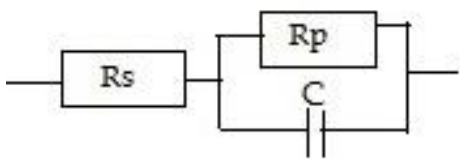

(a)

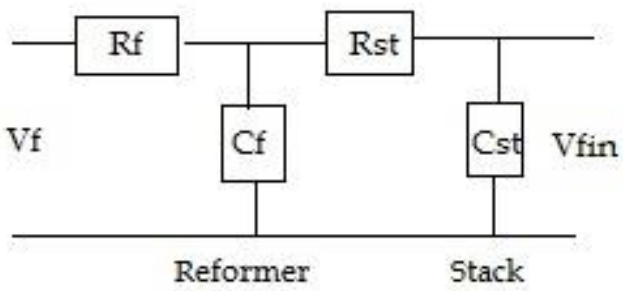

(b)

Fig. 2. Equivalent circuits: (a) Super capacitor (b) Fuel cell.

\section{Series and Shunt Converters}

\subsection{Method of controlling - Series Converter}

The target of the series- filter is to remove the harmonics voltage harmonics [17]. The phase voltages are given at point of common coupling which results into two unit vectors (sinwt, coswt).

The source voltages $\mathrm{V}_{\mathrm{sa}}, \mathrm{V}_{\mathrm{sb}}, \mathrm{V}_{\mathrm{sc}}$ are transformed into d-q-0 from abc, presented in eq. (3.1).

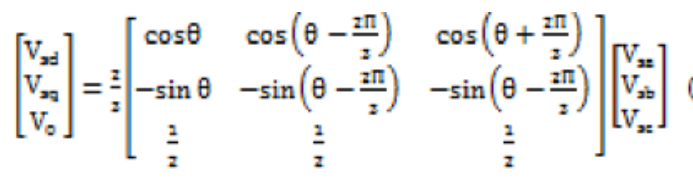

The components of voltages in direct and quadrature axes are given in equation (3.1) and (3.2)

$$
\begin{gathered}
\mathrm{V}_{\mathrm{dh}}=\mathrm{V}_{\mathrm{dDC}}+\mathrm{V}_{\mathrm{dAC}} \\
\mathrm{V}_{\mathrm{qh}}=\mathrm{V}_{\mathrm{qDC}}+\mathrm{V}_{\mathrm{qAC}}
\end{gathered}
$$

To retain the DC bus voltage of the series filter, a PI controlling mechanism is employed and the reference voltage values $\mathrm{V}_{\mathrm{d}}^{*}, \mathrm{~V}_{\mathrm{q}}^{*}$ are given by,

$$
\begin{aligned}
\mathrm{v}_{\mathrm{d}}^{*} & =\mathrm{v}_{\mathrm{dDC}}-\mathrm{v}_{\mathrm{0}} \\
\mathrm{v}_{\mathrm{q}}^{*} & =\mathrm{V}_{\mathrm{qDC}}+\mathrm{v}_{\mathrm{qr}}
\end{aligned}
$$

To get the required compensation reactive component of voltage, use average RMS voltage and reference voltage from the PI controller. Quadrature values are stabilsed to get the required voltage at the converter of series active filter, so that it can be needful to retain the RMS voltage at point of interconnection due to RMS voltage loss by load reactive power. Similarly Inverse-Park transformation is used for getting the reference voltages.

\subsection{Shunt Converter}

Shunt -active power filter is used to handle the linkvoltage at the same time maintain the load current under reactive, non-linear loads.

The $\mathrm{I}_{\mathrm{d}}{ }_{\mathrm{d}}, \mathrm{I}_{\mathrm{q}}{ }_{\mathrm{q}}$ values are

$$
\begin{gathered}
I_{d}^{*}=i_{d D C}+i_{\text {out }} \\
I_{q}^{*}=i_{q D C}+i_{\text {qr }}
\end{gathered}
$$

The two reference currents $\left(\mathrm{i}_{\mathrm{d}}{ }, \mathrm{i}_{\mathrm{q}}{ }_{\mathrm{q}}\right)$ are used to generate the reference load currents, to correct the current magnitude at shunt APF. Here dynamics of shunt active filter senses the current values and is examined with the reference currents to obtain switching pulses. The DC/DC converter is having two full-bridges [9], it works in the dual direction. The working voltage of the fuel cell varies between 60 to $75 \mathrm{~V}$, as well to maintain the link voltage upto $660 \mathrm{~V}$. 


\section{Result Analysis}

\section{(a) Compensation of Voltage Sag and Swells}

A sag in the source voltage is created during $0.3 \mathrm{sec}$ to $0.38 \mathrm{sec}$ in the system. The source voltage \& current, load voltage \& currents, injected voltage and currents are presented in the Fig. 3(a). To retain the load voltage, the super capacitor along with fuel cell unit is injecting the suitable power through the series compensator and it can be observed.

A voltage swell is applied into the system from $0.5 \mathrm{sec}$ to $0.58 \mathrm{sec}$ and the compensating voltage and the instantaneous voltage, load voltage, voltage injected, load current, source current, compen-sation current clearly shown in shown in Fig. 3(b).
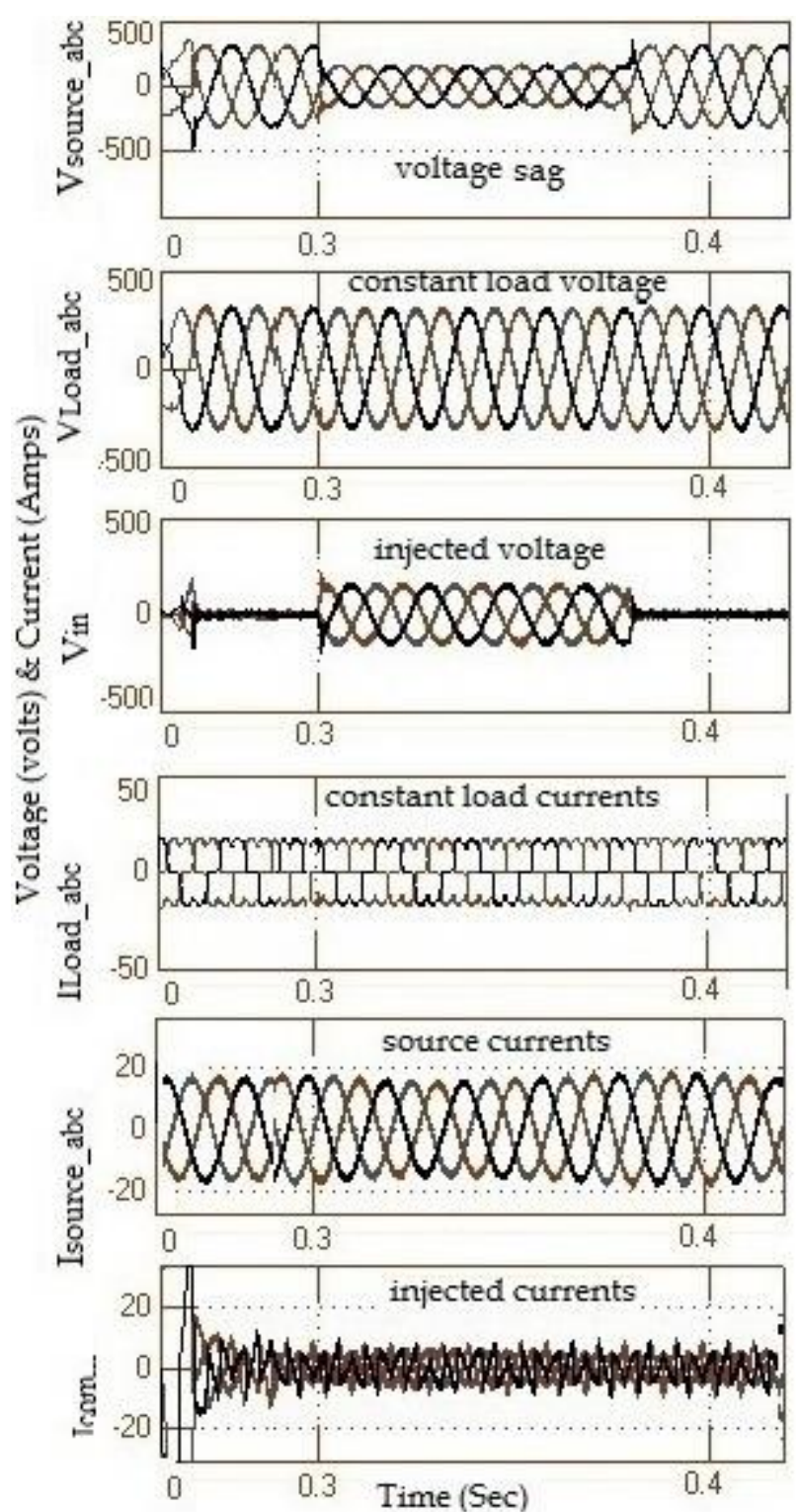

(a)


(b)

Fig. 3. (a) Sag condion (b) Swell condition.

\section{(b) THD Analysis}

The analysis of harmonic distortion shown in Fig.4 a) Source Current b) Load-end voltages shows the percentage THD values of the system are $1.28 \%$ and $2.02 \%$. 


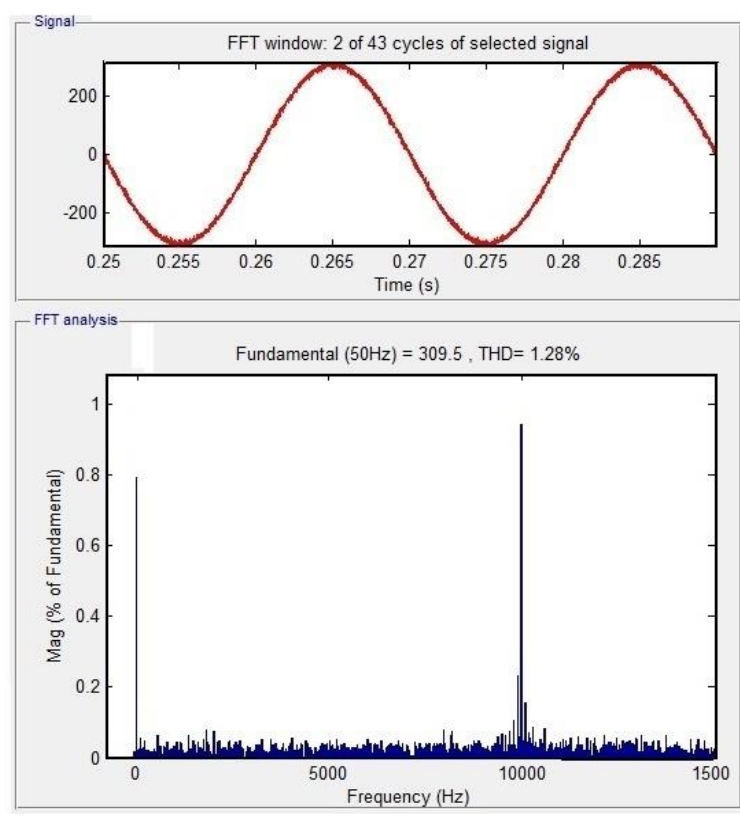

(a)

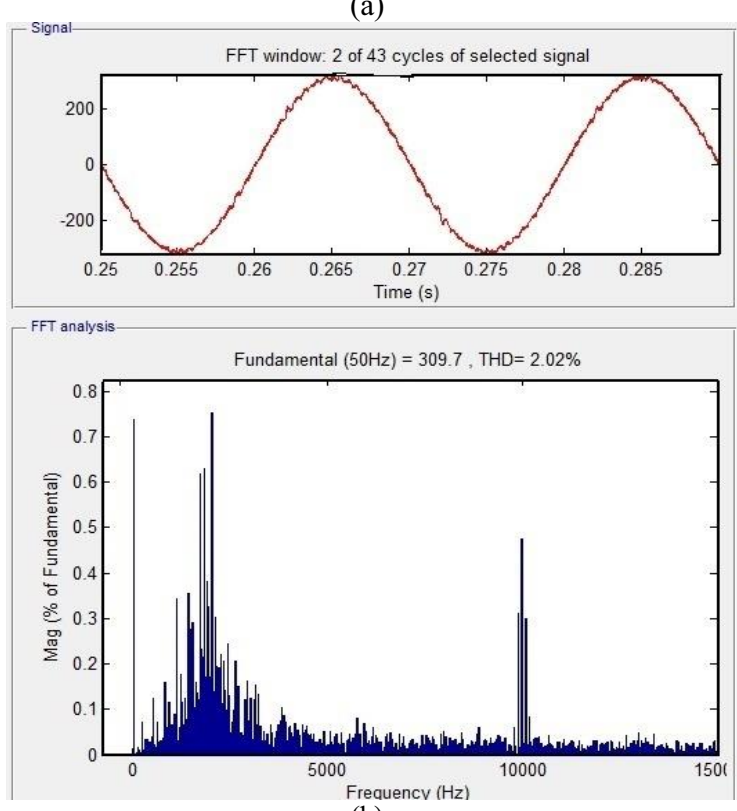

(b)

Fig. 4. Shows the \% THD values of a) Source - side -current b) Load-side voltage of a distribution system.

Table 1. Performance of Hybrid UPQC

\begin{tabular}{|c|c|c|}
\hline $\begin{array}{c}\text { Control } \\
\text { Technique }\end{array}$ & Parameter & \%THD \\
\hline \multirow{2}{*}{ Hybrid UPQC } & $\begin{array}{c}\text { Source Current } \\
\text { (Amps) }\end{array}$ & $1.28 \%$ \\
\cline { 2 - 3 } & $\begin{array}{c}\text { Load Voltage } \\
\text { (Volts) }\end{array}$ & $2.02 \%$ \\
\hline
\end{tabular}

\section{Conclusion}

The concept of hybrid configuration of supercapacitor additionally fuel cell unit attached to UPQC. The UPQC addresses the current, voltage issues. For perfect running conditions, THD of source current with respect to standards of IEEE 519-1992 allowable scale is 5\%. The THD of the source current is $1.28 \%$, the arrangement is simulated under distorted conditions.

Acknowledgements. I thankful to Head Dr. C.Venkatesh and Principal Dr. K. Ashoka Reddy and Management KITSW for their support and motivation.

\section{References}

1. B. Han, B. Bae, H. Kim and S. Baek, "Combined operation of unified power-quality conditioner with distributed generation," in IEEE Transactions on Power Delivery, 21, issue no. 1, pp. 330-338, (2006)

2. H. Akagi, Y. Kanazawa and A. Nabae, "Instantaneous Reactive Power Compensators Comprising Switching Devices without Energy Storage Components, " in IEEE Transactions on Industry Applications, IA-20, issue no. 3, pp.625-630, (1984) 3. N. Kumarasabapathy and P. S.Manoharan, "MATLAB Simulation of UPQC for Power Quality Mitigation Using an Ant Colony Based Fuzzy Control Technique" http://dx.doi.org/10.1155/2015/304165, Article ID 304165, pp.1-9, (2015)

4. Yunbo Long, Xiangning Xiao, Yonghai Xu, Baolai Yu, Yunfei $\mathrm{Xu}$ and Junwei Hao, "MMC-UPQC: Application of Modular Multilevel Converter on Unified Power Quality Conditioner," 978-1-4799-1303-9/13/\$31.00 IEEE, (2013)

5. T.A. Nergaard, J.F. Ferrel, L.G. Leslie and J.S. Lai, "Design considerations for a $48 \mathrm{~V}$ Fuel Cell to Split single phase inverter system with ultra capacitor energy storage," in Proc. IEEE/PESC, Cairns, Australia, June 23-27, Vol.4, pp.20072012, (2002)

6. Belgacem Toual,Lakhdar Mokrani,Abdellah Kouzou, Mohamed Machmoum, "Power Quality and Capability Enhancement of a Wind-Solar-Battery Hybrid Power System", Periodica Polytechnica Electrical Engineering and Computer Science, 64(2), pp. 115-132, (2020)

7. P.B.Karandikar, D.B.Talange, Uday Mhaskar, Ramesh Bansal, "Development, characterization and modelling of aqueous metal oxide based Super-Capacitor", Energy, Elsevier, Vol 40, pp 131-138, (2012)

8.P.B.Karandikar, D.B.Talange, Uday Mhaskar, Ramesh Bansal, Materials and manufacturing processes, "Investigations in to material and manufacturing aspects of aqueous SuperCapacitor", Taylor and Francis, 27 (11), pp. 1164-1170, (2012)

9. https://www.fuelcellstore.com

10. Yang Zhang, Shengfa Zhang, Jiahong Chen," The Applications of Bidirectional Full-bridge DC-DC Isolated Converter in UPQC", Electrical Machines and Systems, pp.1916 - 1921, (2008)

11. Kian Hoong Kwan, Member, IEEE, Kuan Tak Tan, Student Member, IEEE, Ping Lam So, Senior Member, IEEE: « $A n$ Unified Power Quality Conditioner for Load Sharing and Power Quality Improvement", 978-1-4577-1559-4/12/\$26.00 IEEE, (2012)

12. Maurício Aredes and Rodrigo M. Fernandes "A Unified power quality conditioner with voltage sag/swell Compensation capability", IEEE conference, pp. 218 -224, (2009) 
13. B. Vural, A.R. Boynuegri, I. Nakir, O. Erdinc, A. Balikci, M. Uzunoglu,H. Gorgun, S. Dusmez, "Fuel cell and ultracapacitor hybridization: A prototype test bench based analysis of different energy management strategies for vehicular applications" International Journal of Hydrogen Energy, vol.35,issue no. 20, pp. 11161-11171, (2010)

14. Pratik Ranjan Behera, Ritesh Dash, S.M Ali, Kunjan Kumar Mohapatra, "A REVIEW ON FUEL CELL AND ITS APPLICATIONS", IJRET, eISSN: 2319-1163, Vol.3, issue no 3, pp. 563-565, (2014)

15. Jin-Woo Jung and Ali Keyhani, "Control of a Fuel Cell Based Z-Source Converter", IEEE TRANSACTIONS ON ENERGY CONVERSION, Vol. 22, issue no. 2, pp. 467- 476, (2007)

16. X. Yu, M. R. Starke, L. M. Tolbert and B. Ozpineci, "Fuel cell power conditioning for electric power applications: a summary" IET Electric Power Applications, Vol.1, issue no. 5, pp. 643-656, (2007)

17. Bhim Singh, Ambrish Chandra and Kamal Al-Haddad Power Quality: Problems and Mitigation Techniques, WILEY, February, ISBN: 978-1-118-92205-7, (2015)

18. Bei Gou, Woon Ki Na, Bill Diong,"FUEL CELLS Modeling, Control and Applications", CRC Press, pp 2, (2010) 